\title{
Managerial conceptual competencies and the performance of small and medium-sized enterprises in Zimbabwe
}

\begin{tabular}{|c|c|}
\hline \multicolumn{2}{|c|}{$\begin{array}{l}\text { Authors: } \\
\text { Nhamo Mashavira }{ }^{1} \\
\text { Crispen Chipunza }^{1} \text { (I) }\end{array}$} \\
\hline \multicolumn{2}{|c|}{$\begin{array}{l}\text { Affiliations: } \\
{ }^{1} \text { Business Management, } \\
\text { Management Sciences, } \\
\text { Central University of } \\
\text { Technology, Bloemfontein, } \\
\text { South Africa }\end{array}$} \\
\hline \multicolumn{2}{|c|}{$\begin{array}{l}\text { Corresponding author: } \\
\text { Nhamo Mashavira, } \\
\text { mashaviranhamo@gmail. } \\
\text { com }\end{array}$} \\
\hline \multicolumn{2}{|c|}{$\begin{array}{l}\text { Received: } 02 \text { Nov. } 2020 \\
\text { Accepted: } 01 \text { July } 2021 \\
\text { Published: } 31 \text { Aug. } 2021\end{array}$} \\
\hline \multicolumn{2}{|c|}{$\begin{array}{l}\text { How to cite this article: } \\
\text { Mashavira, N. \& Chipunza, C., } \\
2021, \text { 'Managerial conceptual } \\
\text { competencies and the } \\
\text { performance of small and } \\
\text { medium-sized enterprises in } \\
\text { Zimbabwe', Southern African } \\
\text { Journal of Entrepreneurship } \\
\text { and Small Business } \\
\text { Management 13(1), a386. } \\
\text { https://doi.org/10.4102/ } \\
\text { sajesbm.v13i1.386 }\end{array}$} \\
\hline \multicolumn{2}{|c|}{$\begin{array}{l}\text { Copyright: } \\
\text { (c) 2021. The Authors. } \\
\text { Licensee: AOSIS. This w } \\
\text { is licensed under the } \\
\text { Creative Commons } \\
\text { Attribution License. }\end{array}$} \\
\hline \multicolumn{2}{|l|}{ Read online: } \\
\hline 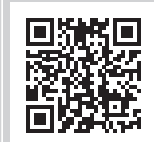 & $\begin{array}{l}\text { Scan this QR } \\
\text { code with your } \\
\text { smart phone or } \\
\text { mobile device } \\
\text { to read online. }\end{array}$ \\
\hline
\end{tabular}

Background: Literature is replete with evidence on the impact of managerial competencies on firm performance. Yet, there is minimal evidence on how managerial conceptual competencies in particular, affect the performance of small and medium enterprises (SMEs) in Zimbabwe.

Aim: The current study was meant to find the impact of managerial conceptual competencies on the performance of SMEs in Zimbabwe's Harare Province.

Setting: The under-exploration of the relationship between managerial conceptual competencies and SME performance, in an economy that at present is highly informalised, provides a platform for further exploration of this phenomenon.

Methods: The study adopted a purely quantitative approach that employed a structured direct survey design.

Results: The study established that owners and/or managers had reasonable levels of conceptual competencies and that SMEs performed fairly well in terms of both innovation and return on investment (ROI). It was found out that statistically significant relationships existed between managerial conceptual competencies and SME performance when measured by innovation and ROI.

Conclusion: In view of the results, it can be concluded that the performance of SMEs in terms of innovation and ROI can be influenced, to some extent, by owner and/or managers' conceptual competencies.

Keywords: managerial competence; conceptual competencies; performance; SMEs; Zimbabwe.

\section{Introduction}

Small and Medium Enterprises (SMEs) are well acknowledged globally for their substantial contributions in the areas of employment, promotion of exports, output, and nurturing entrepreneurship. They account for over $55 \%$ of the gross domestic product (GDP) and over $65 \%$ of total employment in the high-income countries (Li, Jiang \& Li 2020). Small and Medium Enterprises provide over $70 \%$ of total employment and $60 \%$ of GDP in low-income countries (Li et al. 2020). In the EU countries and even the USA, estimates suggest that SMEs provide over $60 \%$ of the employment, $40 \%-60 \%$ of the GDP and contribute $30 \%-60 \%$ of exports (The Zimind 2017). In emerging economies, the SME sector contributes about $45 \%$ of aggregate employment and up to 33\% of the GDP (Organisation for Economic Cooperation and Development 2017). Japan has the biggest share of SMEs among the developed countries, comprising $99.7 \%$ of total enterprises (Saka \& Chan 2020). In South Africa, SMEs make 91\% of the formal businesses, contributing between $51 \%$ and $57 \%$ of the GDP and providing about $60 \%$ of employment (Cant \& Wiid 2013).

According to Mukoswa (2020), the United Nations Industrial Development Organisation estimates that Small, Medium and Micro Enterprises (SMMEs) comprise $90 \%$ of private businesses in developing countries, contributing above 50\% of employment and GDP in most African countries. The Finscope Micro, Small and Medium Enterprises (MSME) Survey (2013) revealed that $46 \%$ of the adults in Zimbabwe run a SME. In Zimbabwe, SMEs employ more than $60 \%$ of the country's labour force and contribute about 50\% of the GDP (Nyathi et al. 2018). The Finscope MSME survey report further revealed that Zimbabwe has over 3.5 million small enterprises in the hands of 2.8 million entrepreneurs. This suggests that one out of every five people in Zimbabwe 
run a business. The above statistics suggest beyond reasonable doubt that SMEs play a significant role in African economies, and their performance should be a cause of concern for both governments as well as academicians.

Given the critical role played by SME performance in their survival, it may be necessary to consider what performance entails. The term performance is often used in academia to describe the results of a firm's activities (Kotane \& KurziminaMerlino 2017). According to Ncube and Chimucheka (2019), a firm's performance refers generally to how well or badly a firm performs in view of the agreed objectives. Kotane and Kurzimina-Merlino (2017), observe an evolution towards merging financial and non-financial measures in the measurement of business performance. Firm performance can therefore be measured using objective measures like return on investment (ROI) and non-financial measures (or subjective measures) such as innovation (Veliu \& Manxhari 2017). Unfortunately, there is no agreed upon method for identifying, measuring, and assessing financial and nonfinancial performance indicators (Kotane \& KurziminaMerlino 2017). This, therefore, calls for higher level competencies among entrepreneurs.

The Finscope MSME survey (2013) reveals that $46 \%$ of SME owners in Zimbabwe have limited exposure to any managerial skills or knowledge. Consequently, the paucity of requisite competencies among owners and/or managers has an impact on the performance of SMEs (Aidara et al. 2021). Yet, the higher the level of competency possessed by SME owners, the greater are their chances of survival (Tola \& Chimucheka 2018). The primary cause behind the failure of SMEs revolved around entrepreneurship management skills, which may include financial management, human resource management, start-up, social and interpersonal, leadership, marketing, personality, business and technical management skills (Mamabolo, Kerrin \& Kele 2017). Entrepreneurs, particularly those operating in the SME sector, face several situations requiring them to make quick decisions. Therefore, high levels of conceptual competencies are imperative for both the success and survival of their businesses (Vijay \& Ajay 2011).

A study by Bushe (2019) on SMMEs in South Africa, established that chief amongst the causes of the enterprises' failure was entrepreneur incapacity. By entrepreneurial incapacity, the author meant that entrepreneurs lacked the skills, knowledge and aptitude to both form and nurture a successful business. Regarding Zimbabwe, recent studies (Majukwa 2019; Njanike 2019) on SMEs confirmed the critical role played by managerial expertise in sustaining SME profitability. However, the aforementioned studies, like many of their predecessors, tend to lump competencies together, hence precluding helpful and accurate feedback, and leads to questioning exactly what it means to attain competence (Norman, Norcini \& Bordage 2014). Therefore, there remains an evident dearth of studies on how managerial conceptual competencies of SME owners and/or managers in an African country, in particular, affect business performance. Accordingly, this study examines the impact of managerial conceptual competencies on business performance in SMEs in Harare Province, Zimbabwe.

\section{Research Purpose and Objectives}

The term competency (plural competencies) has been popularised in human resources management; and of late, in training and career guidance. While on one hand, the term 'competent' from which 'competence' is derived has a clear and diverse meaning (Evangelista 2011), on the other hand, there are many definitions of the term competency as it is commonly used in real activities for people affirmation of their potential to work (Konigova, Urbancova \& Fejfar 2012). Two key connotations upon which definitions of competencies are commonly based exist. According to Königová et al. (2012), the first meaning treats competencies as a scope and power of authority linked to a certain body or person, while the second considers it as the capacity - that is capabilities to do specific activities, to have certain characteristics and skills, to be qualified in a given discipline. In general, competencies are a set of specific knowledge, abilities, traits, motives, skills, values and attitudes necessary for an individual's development and effective involvement in an organisation (Königová et al. 2012). Managerial competencies can be defined as a set of skills, attitude, knowledge and behaviour that an individual requires to be effective in a number of jobs and various types of organisations (Manxhari, Veliu \& Jashari 2017). They can also be understood as the right combination of behaviours, knowledge and skills possessed by a person and could be a source of sustained organisational performance (Gunawan \& Aungsuroch 2017). The role played by managerial competencies in the performance of businesses still remains a vital matter within organisational literature (Mitchelmore \& Rowley 2010). Therefore, a competency, being an individual trait, can be measured reliably and can help differentiate superior performers from mediocre, or productive performers from the unproductive ones (Yuliandi 2014).

The seminal work by Chandler and Jansen (1992) maintains that an effective manager must be competent in three areas viz., conceptual, interpersonal and political. Conceptual competencies, which involve the mental ability to manage all of the firm's activities and interests, are related to the capacity to think out of the box by way of stimulating new thinking patterns and developing new ideas which may even require diverting from normal procedures of doing things (Chandler \& Jansen 1992). Although the relationship between managerial competencies and enterprise success remains an important matter within literature (Ofei, Paarima \& Barnes 2020), it is unfortunate that research on this relationship is not considered adequate and needs further inquiry (Sidek \& Mohamad 2014). Worse still, research on the competence-performance nexus among SMEs in Zimbabwe is still in its infancy. Yet, issues pertaining to the development of individual competencies are increasing as a result of the continuous search for sources of performance and improving the performance of managerial employees (Szczepańska-Woszczyna 2014). 
Regarding the development of individual competencies, the human capital theory regards education as a key investment that influences development of owners and/or managers' competencies (Becker 1964). When owners and/or managers increase their education, they are expected to gain more knowledge which is likely to increase their ability to run the enterprises successfully (Mahadalle \& Kaplan 2017). However, generalisations could be misleading since the attainment of competencies from investments in education may depend on the targeted competencies to be gained, and the learning environment. Pertaining to another demographic variable gender, Jennings and Cash (2006) found a solid base of empirical research showing that female and male business owners differ in critical ways with respect to their: human and social capital; goals and success criteria; motivations; strategic choices; use of financial capital; and growth orientations. It has been established that women's overall experience, knowledge and skills of engaging into business activities were below average (ed. Naudé 2013). Consequently, female SME owners are more likely to be less motivated to achieve high performance, compared to males, as their time has to be divided between home and work (Hundley 2001). This has a negative impact on their propensity to acquire requisite competencies and even their ability to gain experience which is a requisite for better enterprise performance (Klapper \& Parker 2011), hence the need to consider even the non-economic outcomes of their entrepreneurial activities (Carranza, Dhakal \& Love 2018). On the contrary, Shava and Rungani (2016) maintain that male and female-owned SMEs perform at similar levels, provided owners possess high business-related experience.

While the aforementioned evidence is commendable in terms of highlighting the role of demographic variables and management competencies in the performance of firms, literature on how managerial conceptual competencies in particular affect the performance of Zimbabwean SMEs remains scanty. The under-exploration of this relationship, particularly in an economy that at present is highly informalised, provides a platform for further exploring the phenomenon. Moreover, researchers often make the assumption that entrepreneurial competency (managerial competency being one of its components) distinguishes nonentrepreneurs from entrepreneurs, without carrying out empirical examination and testing such an assumption (Xiang, Worthington \& Higgs 2014). Based on this, the current study aims to determine the impact of managerial conceptual competencies on SME performance in Zimbabwe as measured by ROI and both process and product innovation (simply called innovation in the current study). Both process and product innovation are closely associated with the concept of technological innovation (Akinwale, Adepoju \& Olomu 2017). On the one hand, technological process innovations have to do with new elements that are used in the production process, and include both capital and intermediate goods, such as information technology equipment, processing machines and industrial robots (Hervas-Oliver, Sempere-Ripoll \& BoronatMoll 2014). On the other hand, product innovation involves either the creation of a new product from new materials or modification of existing products to meet customer satisfaction (Rosli \& Sidek 2013). Since Schumpeter (1934) suggested the central role of innovation in economic development in 1934, innovation began to be widely regarded as a vital factor affecting business performance. Innovation and ROI were chosen as measures of performance in the current study because of the emerging trend towards merging both financial and non-financial measures in the measurement of business performance (Kotane \& Kurzimina-Merlino 2017) in order to achieve more balance.

In view of the above, the current study is guided by the following objectives:

- To examine owners and/or managers' demographic characteristics such as gender, education and designation.

- To find out the managerial conceptual competencies of owners and/or managers in SMEs in Zimbabwe.

- To determine the performance of SMEs in Zimbabwe when measured by ROI and innovation.

- To evaluate the impact of managerial conceptual competencies of owners and/or managers on the enterprises' performance.

\section{Problem Background}

The implementation of the Bretton-Woods driven Economic Structural Adjustment Programme (ESAP) in the early 1990s resulted in numerous company closures and retrenchments which made a foundation for a rebound in the SME sector (Jongwe 2011). This was exacerbated by the macroeconomic meltdown which reached its climax in 2008, and did not spare the ordinary citizen. Zimbabwe experienced a 50\% reduction in its economic growth, a $60 \%$ closure of factories, and close to a $100 \%$ drop in foreign currency reserves (Zindiye, Chiliya \& Masocha 2012). Kawaza (2014) indicates that the Retrenchment Board publicised that the number of recorded retrenchments from January to 27 June 2014 stood at just over 2060 in Zimbabwe. This did not reflect the full number of retrenchments, since an estimated 30\% did not apprise the board when retrenching their staff numbers. It is believed that between 100 and 400 employees were retrenched every week (Kawaza 2014).

Furthermore, pursuant to the Supreme Court judgement in Don Nyamande and Another versus Zuva Petroleum (Pvt) Ltd delivered in July 2015, affirming an employer's common law right to terminate unilaterally a contract of employment on notice, employees were left exposed to the caprice of unscrupulous employers (Mucheche 2017). Thousands of workers were fired on 3 months' notice, aggravating the high unemployment levels existing in the country. This inevitably led to an increase in 'informal businesses' occupying every empty space in urban areas - in the form of flea markets, craft shops and vendors, selling all kinds of wares, including airtime, fruit, furniture and clothing. The main motive to start a business was survival, with $63 \%$ of SME owners being driven by poverty, unemployment, the need to provide for family and other related reasons (Finscope MSME Survey 2013). 
Interestingly, Aidara et al. (2021) revealed that entrepreneurial competencies showed a significant and positive influence on the performance of informal entrepreneurs in Senegal. Another study by Majukwa (2019) meant to explore the strategies used by the Zimbabwean SME owners to sustain their businesses established that enriching management competencies through enhancing the strategies used by SMEs owners to remain in business might help businesses compete more effectively. Owners and/or managers knowledgeable of managing the intricacies of starting a business could easily maximise workforce capabilities to increase revenue and sustain growth (Majukwa 2019). Owners and/or managers were found to perform badly in the vital management areas of market development, trade promotion, access to finance, and the creation of a conducive legal framework (Majukwa 2019). Yet, the following skills are generally agreed to be important for entrepreneurs: management skills (the ability to nurture management systems, coordination, and organisation), idea generation, analytical and conceptual competencies, the ability to recognise and exploit opportunities, customer management skills, decision-making skills, motivation and delegation skills, the ability to develop strategies for exploiting opportunities, hiring, commitment, and leadership skills (Mitchelmore \& Rowley 2010). Other studies (Alene 2020; Gizaw, Tsega \& Hailegiorgis 2019) also established that entrepreneurs' demographic, behavioural and psychological characteristics, their technical know-how and managerial skills are often mentioned as germane determinants of an SME's performance. Furthermore, some studies (Carranza et al. 2018; Mozumdar, Van Der Velde \& Omta 2020) purport that human factors such as knowledge, skills and experience of the owners and/or managers and employees are the key distinctive competencies of small firms.

\section{Literature review and hypotheses development}

\section{The resource-based view}

The resource-based view (RBV), originated by Penrose (1959) was popularised by Barney (1991). The RBV mainly proposes that the strategic advantage of a business is buttressed by its core competencies, which provide competitive advantage that is sustainable and can be attained through the availability of resources and the employment of a resources management strategy (Barney 1991; Wernerfelt 1984, 1995). The RBV holds that it is possible to realise competitive advantage through deployment of capabilities and resources. According to the $\mathrm{RBV}$, it is the combination of capabilities and resources that could differentiate one business from the other, and will permit a business's superior offerings (Agyapong, Ellis \& Domeher 2016). The RBV maintains that effective firms will find their future leverage by developing unique capabilities, which are likely to be intangible or implicit in their nature. However resource unavailability is one weakness of SMEs. Most SMEs lack in size-specific advantages, finance, and the businesses' ability to use their capabilities to the most.
The theory maintains that not all business resources are important in enabling it to create a competitive advantage. A sustainable competitive advantage could be achieved if the resources are valuable, inimitable, non-substitutable, and nontransferable (Barney 2001, 1991; Kraaijenbrink, Spender \& Groen 2009; Peteraf 1993). A firm's resources comprise tangible, external and intangible assets. Tangible assets include physical resources like plant, land, equipment or stocks, which are visible and can be assessed (Wilk \& Fensterseifer 2003). According to Grant (1991), tangible resources can either be physical assets or financial. Intangible assets such as organisational routines and processes, human capabilities, networks or patents are neither visible nor quantifiable (Wilk \& Fensterseifer 2003). External resources include knowledge and relationships acquired through interactions with customers, suppliers, competitors, and other institutions. Intangible resources are regarded as the most significant from a strategic viewpoint (Lockett \& Thompson 2001).

The RBV literature (Barney 1991, 1986a, 1986b; Rumelt 1987) holds that performance and competitive advantage outcomes result from firm-specific capabilities and resources that are costly to replicate by rivals. Although resources like economies of scale, technology, finance and natural resources could generate value, the RBV asserts that such centres of value are accessible to all, and are also easily replicated when compared to complex resources such as human resources (Barney 1991). Ever since the seminal work by Penrose (1959), there has been a phenomenal growth in managerial competencies literature (Mitchelmore \& Rowley 2010), as the identification and development of owners/manager competencies would give venture firms an edge over competitors.

\section{Managerial conceptual competencies and firm performance}

According to Katz (2009):

$[C]$ onceptual skill involves the ability to see the enterprise as a whole; it includes recognizing how the various functions of the organization depend on one another, and how changes in any one part affect all the others; and it extends to visualizing the relationship of the individual business to the industry, the community, and the political, social, and economic forces of the nation as a whole. (p. 18)

Managerial conceptual skills can be regarded as the cognitive ability to view the firm as a whole and the connection between its parts (Ikupolati et al. 2017). It, therefore, encompasses the entrepreneur's information processing, thinking and planning abilities. Managerial conceptual competencies are needed to strategically plan for enterprises. These competencies permit managers to assess situations and suggest alternative courses of action. Good managerial conceptual skills are a requisite for the top management, who do strategic planning. Managerial conceptual competencies help managerial professionals visualise concepts, analyse potential challenges and design creative solutions (University Canada West 2021). They give managers some strategic advantage as they allow them to predict potential risks and strategise accordingly. Managerial conceptual skills give managers the opportunity to be very 
analytical in working with concepts; be critical thinkers - who can think through ideologies, concepts and philosophies that form the basis of an organisation, its goals and vision (Ofei et al. 2020). These skills (considered a must for both middle and top managers) enable them to ask hypothetical or 'what if' questions, working with abstract ideas (Ofei et al. 2020). Managers can therefore conceptualise and even synthesise abstract ideas for the organisation and for the staff.

As has been alluded to above, it is unfortunate that research on the managerial competence-performance nexus is not adequate and needs further inquiry (Sidek \& Mohamad 2014). The same could be said of the managerial conceptual competence-performance nexus. A study by Ikupolati et al. (2017) established that the managerial conceptual skills of Nigerian entrepreneurs made employees become goal driven and boosted their self-confidence when proffering solutions to challenges they might encounter while executing their duties. As observed by Katz (2009), it is evident that appreciating relationships among an enterprise's parts and recognising the major elements in any situation, enables owners and/or managers to act in ways which advance the overall welfare of the whole enterprise. An empirical study by Lopa and Bose (2014) on the owners and/or managers of SMEs in the manufacturing industry in Khulna City, Bangladesh, identifies six groups of competencies, namely organising, relationship, commitment, strategic, opportunity and conceptual competencies. The study established that all the competencies were needed by entrepreneurs in manufacturing firms to improve their performance (Lopa \& Bose 2014). Another investigation consisting of start-ups and established SMEs reveals that established SMEs considered functional competencies (related to general business management and technical skills) as more vital than start-ups (Botha, Van Vuuren \& Kunene 2015). These findings suggest that start-up firms need to concentrate on the significance of functional competencies if they are to increase the likelihood of being reputable enterprises. The authors found out that, start-ups, and established SMEs regard enterprising competencies (that depend on personal and entrepreneurial skills) as important. Although the current study did not separate established SMEs from start-ups, the business management competencies alluded to in the study by Botha et al. (2015) are related to managerial conceptual competencies.

Mustafa and Ayse (2017) refer to managerial conceptual competencies as administrative skills and hold that entry level managers require less of them compared to technical skills for instance; and that middle level management require a considerable amount of both skills. They further maintain that senior managers, who must have a perspective of the whole enterprise, and an appreciation of how the several functions of the enterprise depend on one another, would require more of administrative and less of technical skills (Mustafa \& Ayse 2017).

Contrary to the studies above, Motlaq et al. (2012) found out that a managerial conceptual skills training among women managers of the Mashhad municipality in Iran seems to have increased their job satisfaction rather than their job performance. What is not clear, however, is whether the causal relationship differs according to the type of organisation under study considering the differences existing between large corporations and the SMEs. Similarly, while minimal work has been done on managerial conceptual competencies in entrepreneurial firms, no known research has attempted to find how they affect SME performance in an African country. The current study, among other things, seeks to close such a gap in literature by suggesting a relationship between managerial conceptual competencies and firm performance. To validate the aforesaid relationships within the context of SMEs in Harare Province, Zimbabwe, the following hypotheses were proffered:

H1: There is a statistically significant relationship between managerial conceptual competencies and SME performance as measured by innovation.

H2: There is a statistically significant relationship between managerial conceptual competencies and SME performance as measured by ROI.

\section{Small and medium enterprise performance}

Firm performance generally refers to how well or badly an enterprise performs relative to agreed objectives (Ncube \& Chimucheka 2019). Small business performance has been associated with their failure or success (Hamid et al. 2018). High performance therefore means a more successful business, and vice versa. Veliu and Manxhari (2017) maintain that business performance can be measured using both objective (and financial) measures like profitability and subjective (or non-financial measures) like innovation. Business performance measures could therefore be grouped into two main categories, namely, 'financial and non-financial measures' (Rashid et al. 2018). Terms, such as financial and operational measures; short- and long-term measures; or finance and efficiency (Johari et al. 2018; Salleh et al. 2018) are often used, but, whatever terms are used, they still revolve around the financial and non-financial criteria. Prior to the 1980s, financial indicators (e.g. profit, ROI and sales per employees) were the only measurement standard of performance, but starting from the 1990s to date, attention has been shifting from financial to non-financial measures such as trust, customer satisfaction, quality of product and so on (Nerisa 2015). The shift to subjective information is reasonable since most SMEs are characterised by informality and poor record keeping. Related to this are the challenges that ordinarily arise from the reluctance by owners and/or managers of most privately owned enterprises to share objective financial data. According to Gupta and Batra (2016), objective measures of business performance are considered to be private and confidential, and are often guarded from the scrutiny of the public. There is unanimity among scholars that financial metrics are still relevant and valid, although there is need to balance them with contemporary, externally focussed and intangible metrics such as innovation, employee satisfaction among others (Bititci, Firat \& Garengo 2013; Yip et al. 2009). It is against this background that this study had to use a balanced approach in 
the measurement of performance so as to meet both nonfinancial results as well as financial results (Chong 2008).

The choice to use ROI as a measure of financial performance was reached because it tells entrepreneurs whether their investment was successful or not (Lee 2012). ROI helps in the assessment of the extent to which a business' resources have been used efficiently, and it also shows the effectiveness of one's investment in the business (Lee 2012). As a result of the formidable challenges linked with the gathering and interpretation of financial data collected from SMEs, mostly owned by private players, researchers have but little choice besides contending with subjective measures of business performance (Dekker et al. 2015). According to Shouyu (2017), the irresistible evidence on the significance of innovation in augmenting a business' ability to adapt to the ever changing business environment resulted in its choice as a subjective performance measure in the current study. Innovation in SMEs lies at the centre of inclusive growth strategies, since more innovative enterprises tend to be more productive, can pay attractive wages and provide better conditions of work to their employees (Organisation for Economic Cooperation and Development 2018). In addition, recent developments in technologies and markets provide new opportunities for SME innovation and growth.

\section{Research methodology \\ Research design}

The study employed a structured direct survey design. It is the most common data collection method and involves questionnaire administration (Malhotra et al. 2017). A typical questionnaire contains questions that require fixed responses from the participants who would have to select from predetermined sets of responses (Malhotra et al. 2017). The survey method has the advantage that questionnaires are easy to administer, and the data obtained is consistent as the responses are limited to given responses (Malhotra et al. 2017). Its other strength lies in that, fixed-response items reduce discrepancies in results that could be caused by differences in interviewers. Consequently, the coding, analysis and even interpretation of data becomes simple.

\section{Research approach}

The quantitative and qualitative approaches are the two approaches generally used to gather and report information in research (Ben-Eliyahu 2014). The decision to take a qualitative or quantitative approach should be based on one's research questions and the nature of the data to be collected and analysed in order to address the question (Matthews \& Ross 2010).

Hughes (2006) posits that qualitative and quantitative approaches are strongly associated with subjectivity and objectivity, respectively. The current study was purely quantitative in its approach. Quantitative research deals with measurement and numbers, and uses standardised measures in order to fit the different perspectives and experiences of the participants into predetermined response categories (Wyllie
2019). The social phenomena under study were regarded as objective in nature and subjects were measured only once.

\section{Research participants}

Owners and/or managers in Harare Province were chosen because the province had a higher concentration of SMEs (Madzivanzira 2011). However, no comprehensive database of SMEs in the province could be found at the Ministry of Small and Medium Enterprises and Cooperative Development; the Informal Traders Association; the Informal Sector Association; and even at the Small Enterprise Development Corporation (SEDCO). It therefore, became unfeasible to draw a comprehensive sampling frame for the SMEs. As a result, convenience sampling had to be used. Some authors (De Vos et al. 2014; Gray 2014) call convenience sampling accidental, volunteer, haphazard, or availability sampling considering that respondents are usually those nearest or most accessible. Convenience sampling is the cheapest and least time-consuming. Sampling units are easy to measure and are often cooperative and accessible (Malhotra et al. 2017). Questionnaires were then distributed after making some introductory remarks (reminiscent of issues covered in the cover page of the questionnaire) to the respondents. Questionnaires were hand delivered and research assistants only availed themselves in the event of the participants encountering problems. Given the geographical scope of the study, research assistants were appointed to assist in the distribution of questionnaires. Two former trained students were chosen to assist in the distribution of questionnaires. A total of 106 questionnaires were completed.

\section{Research instruments}

The researcher used a self-constructed structured questionnaire as the only method of gathering primary data. The selfconstructed items helped measure managerial conceptual competencies, innovation and ROI. Section A solicited biographical information, and the other two sections solicited information on managerial conceptual competencies and firm performance. Section B measured the managerial conceptual competencies of owners and/or managers. The choice of items to measure managerial conceptual competencies was influenced by the seminal work by Chandler and Jansen (1992), Katz (2009) and Papulová and Mokroš (2007), which considered the competencies as a requisite for effective management. Most items for this section were adapted from the Managerial Behaviour Self Rating MSAI-key form (Cameron \& Quinn 2011). Respondents were required to indicate their level of agreement with given statements on a Likert scale, ranging from 1-Strongly Disagree to 5-Strongly Agree. Examples of items used to measure managerial conceptual competencies were: 'I initiate cross functional teams that focus on important issues', and, 'I have developed a clear strategy for helping the business successfully accomplish my vision of the future'. Section $C$ measured firm performance in terms of innovation and ROI for the period 2015 and 2016. Items for Section C were influenced by the works of Anwar (2018); Ismanu et al. (2017) and Emenyoni 
et al. (2014) among others. The section required respondents to indicate their level of agreement with given statements. For example, pertaining to innovation, 'Owner/managers initiated unique improvements to product features in 2015'. Regarding ROI, an example is: 'This firm's overall returns exceeded overall costs in 2015'. The scale: 1 . Strongly Disagree to 5. Strongly Agree was used.

\section{Ensuring reliability and validity}

Reliability deals with the ability of an instrument to reproduce consistent results in time and space, or from different observers, on the aspects of coherence, equivalence, stability, and homogeneity (De Souza, Alexandre \& Guirardello 2017). If research is to be reliable, then, it must show that it was done on similar groups of respondents in the same context (however defined), which will lead to similar results being found. The Cronbach's alpha (or coefficient alpha) of determining internal reliability of instruments was used, since it could easily be integrated into computer software for quantitative data analysis (Bryman \& Bell 2007). This coefficient ranges between 0 and 1 , and a value of 0.6 or less shows that internal consistency reliability will be unsatisfactory. Table 1 shows the reliability statistics results.

A Cronbach's alpha of $0.712(\alpha=0.712)$ is a good reliability measure. It means that all the items were reliable and internally consistent in examining how the two variables relate. Regarding face validity of the instrument, experts were involved in validating the questionnaire items (Sangoseni, Hellman \& Hill 2013). Pilot testing of the instrument was done on SMEs that did not take part in the final study. Pilot testing also allowed the researcher to gauge the suitability of the instrument and accommodate amendments that could increase the instrument's reliability (De Vos et al. 2011).

\section{Research procedure}

Completed hand-delivered questionnaires were collected at an agreed date. As a result, the response rate increased because of the personal contact and the convenience that the process afforded participants (De Vos et al. 2011). Data for the years 2015 and 2016 were gathered.

\section{Statistical analysis}

The SPSS version 20 was used for storing and organising the data. The package also assisted in analysis of demographic data, correlational analysis as well as hypothesis testing.

TABLE 1: Reliability statistics results.

\begin{tabular}{lcc}
\hline Cronbach's alpha & Cronbach's alpha on standardised items & Number of items \\
0.712 & 0.934 & 40 \\
\hline
\end{tabular}

TABLE 2: Gender and education of respondents.

\begin{tabular}{lcccccc}
\hline Variable & \multicolumn{3}{c}{ Gender } & \multicolumn{4}{c}{ Education } \\
\hline Frequency & Male & Female & Primary & Secondary & Diploma & Degree \\
Valid (\%) & 92 & 14 & 3 & 70 & 19 & 14 \\
\hline
\end{tabular}

\section{Ethical considerations}

To begin with, the researcher had to be granted clearance by the Faculty Research Ethics committee. Respondents' consent was sought before participation. The cover page provided room for participants to withdraw if they so wish. The participants were also made aware of the intended use of the information. Data had to be stored in ways that precluded unauthorised access in order to ensure confidentiality.

\section{Research findings Demographic variables}

The biographical information was mainly categorical in nature. A categorical variable is one that can take on one of a limited, and normally fixed number of possible values, allocating each individual or other unit of observation to a particular category or nominal group on the basis of some qualitative characteristic (Kaur 2013). That is, they can only be measured in terms of whether the concerned items belong to certain distinct groups, but one cannot quantify or even rank order the categories (Kaur 2013). Descriptive statistics were employed in describing categorical variables. Table 2 shows the gender and education of the respondents. According to Table 2, males dominated in either the ownership or management of SMEs, and a majority of respondents had a secondary education.

Table 3 shows the designation of respondents. According to Table 3, many respondents were owner-managers, and very few HR managers took part in the survey.

Table 4 shows the data regarding managerial conceptual competencies of owners and/or managers and firm performance.

Average mean scores ranging between 3.62 and 4.12 on the Likert scale ranged from 1 Strongly Disagree (1) to Strongly Agree (5), suggest moderate agreeability. Conceptual competence was measured using 19 items, whose mean was 4.12 , median 4.00 and a standard deviation of 0.26 . Innovation and ROI were each measured using six items whose means, medians and standard deviations are shown in Table 4.

TABLE 3: Designation of respondents.

\begin{tabular}{lcccc}
\hline Variable & \multicolumn{4}{c}{ Designation of respondents } \\
\cline { 2 - 5 } & Owner & Manager & $\begin{array}{c}\text { Owner and } \\
\text { manager }\end{array}$ & $\begin{array}{c}\text { Human } \\
\text { Resource } \\
\text { manager }\end{array}$ \\
\hline Frequency & 31 & 25 & 42 & 5 \\
Valid (\%) & 30.1 & 24.3 & 40.8 & 4.9 \\
\hline
\end{tabular}

TABLE 4: Managerial conceptual competencies and firm performance.

\begin{tabular}{lcccc}
\hline Variable & $N$ valid & Mean & Median & Standard deviation \\
\hline $\begin{array}{l}\text { Conceptual } \\
\text { competencies }\end{array}$ & 99 & 4.12 & 4.00 & 0.26 \\
$\begin{array}{l}\text { SME performance - } \\
\begin{array}{l}\text { Innovation } \\
\text { SME performance-ROI }\end{array}\end{array}$ & 106 & 3.88 & 4.00 & 0.624 \\
\hline
\end{tabular}

SME, Small and Medium Enterprise; ROI, return on investment 


\section{Managerial conceptual competencies versus innovation}

In assessing the impact of managerial conceptual competencies on innovation, Spearman's correlation coefficient was used. Table 5 reports the results that were found.

Results as reported in Table 5, show a correlation coefficient value of 0.324 implying a weak positive correlation between the two variables. Furthermore, the correlation is statistically significant at $1 \%$ as supported by a $p$-value of 0.000 which is less than 0.01 . We, therefore, reject the null hypothesis and accept the alternative hypothesis which says that: there is a statistically significant relationship between managerial conceptual competencies and SME performance, as measured by innovation.

\section{Managerial conceptual competencies versus return on investment}

In assessing the impact of managerial conceptual competencies on ROI, Spearman's correlation coefficient was again used, and the results are reported in Table 6.

Results in Table 6 show a weak positive correlation of 0.332 between managerial conceptual competencies and business performance measured using ROI. The correlation is statistically significant at $1 \%$ as supported by a $p$-value of 0.000 which is smaller than 0.01 . We, therefore, reject the null hypothesis and conclude that there is a statistically significant relationship between managerial conceptual competencies and SME performance as measured by ROI.

\section{Discussion of findings Gender and education}

According to Table 2, males dominated in either the ownership or management of SMEs. They comprised $86.8 \%$ of the research

TABLE 5: Spearman's correlation on managerial conceptual competencies versus innovation.

\begin{tabular}{llcc}
\hline Spearman's Rho & Variable & $\begin{array}{c}\text { Conceptual } \\
\text { competencies }\end{array}$ & Innovation \\
\hline Conceptual & Correlation coefficient & 1.000 & $0.324 *$ \\
competencies & Significance (2-tailed) & - & 0.000 \\
& $N$ & 106 & 106 \\
Innovation & Correlation coefficient & $0.324 *$ & 1.000 \\
& Significance (2-tailed) & 0.000 & - \\
& $N$ & 106 & 106 \\
\hline
\end{tabular}

*, Correlation is significant at the 0.01 level (2-tailed).

TABLE 6: Spearman's correlation on managerial conceptual competencies versus return on investment.

\begin{tabular}{llcc}
\hline Spearman's Rho & Variable & $\begin{array}{c}\text { Conceptual } \\
\text { competencies }\end{array}$ & ROI \\
\hline Conceptual & Correlation coefficient & 1.000 & $0.332 *$ \\
& Significance (2-tailed) & - & 0.000 \\
& $N$ & 106 & 106 \\
ROI & Correlation coefficient & $0.332 *$ & 1.000 \\
& Significance (2-tailed) & 0.000 & - \\
& $N$ & 106 & 106 \\
\hline
\end{tabular}

ROI, return on investment.

*, Correlation is significant at the 0.01 level (2-tailed). participants. Slightly over 31\% of the participants had either a diploma or university degree, whose relevance to the industry was not ascertained. According to Lopez-Nicolas et al. (2020), male entrepreneurs outnumber their female counterparts, as female entrepreneurs encounter many challenges in starting and sustaining a business. The fact that fewer start-ups made by females survive to maturity when compared to their male counterparts (Minniti 2017), could explain why male participants dominated in the current study.

Regarding gender of owners and/or managers, studies have found it to significantly predict management problems and success only when it is combined with other moderating variables (Collins-Dodd, Gordon \& Smart 2004; Tocher \& Rutherford 2009). Other studies (DeTienne \& Chandler 2007; Lopez-Nicolas et al. 2020) established that positive results among female-owned firms confirm that women occupying top managerial positions are a unique resource, with a specific innovation capacity and a distinct behaviour regarding experimentation, thus, supporting the notion that women tend to be more engrossed with learning-innovating sequences than men. The extent to which gender of the entrepreneur affects SME performance is an area that requires rigorous study since a lot of nuances and myriads of moderating variables need to be considered in the nexus. It is again beyond the scope of the current study to delve into these issues.

The main reason to start businesses in Zimbabwe was survivalist (irrespective of one's education), with $63 \%$ of SME owners being driven by poverty and unemployment (Finscope MSME Survey, Zimbabwe 2013). Yet, competencies were found to be related to entrepreneur characteristics like education, motivation or work experience (Santos \& Bode 2012). This study's findings resonate well with Bushe (2019), who established that chief amongst the causes of the enterprises' failure was entrepreneur incapacity in terms of skills, knowledge and aptitude to both form and nurture a successful business. Herrington and Wood (2003) maintained that lack of training and education reduced the capacity of management in new businesses in South Africa, and was one among many reasons behind low levels of entrepreneurial creation and high rate of failure of new ventures. Mamabolo et al. (2017) identified the main cause of SME failure among South African entrepreneurs to be lack of entrepreneurship management skills. The requisite competencies could be labelled as financial management, human resource management, start-up, social and interpersonal, leadership, marketing, personality, business and technical management skills (Mamabolo et al. 2017). In view of this, they reached the conclusion that the aforementioned skills framework could serve as a baseline for skills training, mentoring, support and development programmes meant to develop critical and practical skills required in entrepreneurship - even amidst a weaker overall educational system, levels of entrepreneurship activity could thus be enhanced.

Findings from a related study that tested a novel framework to investigate problems related to Human Resource Management (HRM) in SMEs - established that more 
experienced SME owners and/or managers were more likely to perceive HRM problems as acute (Tocher \& Rutherford 2009). Furthermore, SME owners and managers who had a college degree were more likely to consider HRM problems as serious. The fact that more educated and experienced managers perceived HRM problems could be a result of the attention they gave to such issues. Experience and education increase the likelihood that owners and/or managers become conscious of the serious nature of the HRM problems, while their less-enlightened counterparts may not notice problems because of the ignorance of the manifest symptoms (Rutherford et al. 2004). This could explain why, in spite of the low education levels of owners and/or managers in the current study, they still responded in affirmative to items measuring their conceptual competencies. Interestingly, a study carried out on immigrant-owned SMEs in South Africa, assessing the impact of managerial competencies on performance of the enterprises indicated a relationship between education and the performance of owners (Fatoki 2014). The study, however, discovered that higher education levels (Matric and above) were insignificantly related to enterprise performance. Similarly, a more recent study by Chundu, Pindiriri and Kaseke (2020) on Zimbabwean MSMEs found out that although the coefficient on education variable had a significant positive relationship with the firm's growth in case of sole proprietors and micro-enterprises, it was, however, insignificant in the case of SMEs. In conclusion, research evidence on whether education level has a bearing on SME performance or not, remains eclectic and inconclusive because of the contextual differences and the fact that different studies use different proxies like number of employees, balance sheet size and turnover for size.

\section{Designation of respondents}

Most of the participants (40.8\%) in the survey were ownermanagers, and very few enterprises had HR departments (4.9\%). As has been observed by Forth and Bryson (2018), SMEs are less likely to use formal management practices (that could require a fully-fledged HR department) when compared to larger firms, although such practices bring demonstrable advantages for those who use them. Furthermore, in SMEs, where resources may be limited, there may be very few formal human resource professionals or departments, and informal hiring practices are natural, given the cost concerns and the firm's structure (Singh, Rigsby \& Ramgulam 2018). Unfortunately, in the absence of an HR department, its duties are delegated to other departments, and yet enterprises stand to benefit from it. An HR department helps streamline activities, creates a fair, transparent and impartial system that could deliver equal employment prospects, justifiable promotions, tracks employee tenures and provides solutions to queries on insurance and medical issues, amongst others (Umer 2012). The HR department would even assist create an organised organisational structure with justifiable grading and pay structures, benefit schemes, promotion and employee compensation plans among other numerous advantages (Umer 2012). The sheer lack of managerial capacity and culture in these firms results in managerial techniques and tools being perceived as of minimal benefit to the firm (Pekkola, Saunila \& Rantanen 2016). Frequently, employees occupy several positions at the same time, organisation structures are flat, and though the owner-manager is in charge of both managerial and operational functions, managerial activities are usually neglected (Barisic \& Boricevic 2013).

\section{Performance of Small and Medium Enterprises in Zimbabwe}

Innovation and ROI were each measured using six items whose means, medians and standard deviations are shown in Table 4. Mean scores of 3.88 and 3.62 for innovation and ROI, respectively, suggest moderate performance. A survey on Zimbabwean SMEs by Makanyeza and Dzvuke (2015) established that although the influence of innovation on the enterprise performance varied according to the type of industry, SMEs were found to be somewhat innovative. These results are in agreement with those established by the current study. Surprisingly, a study by Mpando (2015) on SMEs in the Harare metropolitan, found no significant difference on the impact of innovation on SME performance across educational level, level of management and gender. Although literature on the financial performance of Zimbabwean SMEs is scanty, Maseko and Manyani (2011) revealed that most SMEs do not maintain adequate records of accounts because of inadequate accounting knowledge, hence the inefficient use of accounting information in the measurement of financial performance. Even if the information might be available, it may be imperfect and inaccurate because of poor record keeping that characterise most SMEs. Worse still, according to Maseko and Manyani (2011), owners and/or managers in SMEs do not value profitability (of which ROI is one other measure of profitability) as a measure of enterprise performance, although they are compelled to compute profits for the purposes of tax.

\section{Managerial conceptual competencies among Small and Medium Enterprises owners and/or managers in Zimbabwe}

The study established that owners and/or managers possessed fairly reasonable levels of conceptual competencies. An average score of 4.12 for 19 items measuring managerial conceptual competencies on the Likert scale ranged from Strongly Disagree (1) to Strongly Agree (5), suggests moderate agreeability. Literature on the managerial competencies of owners and / or managers of Zimbabwean SMEs is still limited and to date, no known studies on managerial conceptual competencies have been done. However, peripheral studies (Gwatsvaira \& Mtisi 2016; Sandada \& Mangwandi 2015) alluding to management competencies in general, identified lack of management skills (among a plethora of other factors) as causal to poor SME growth and performance. Unlike the aforementioned studies, the current study measured a specific competence among owners and/or managers. Contrarily, this study established that the owners and/or managers possessed moderate managerial conceptual competencies, which had 
weak positive correlations of 0.332 and 0.324 with ROI and innovation, respectively.

\section{Managerial conceptual competencies and firm performance}

A statistically significant relationship between managerial conceptual competencies and firm performance as measured by both ROI and innovation was established. Although there is a paucity of literature on managerial conceptual competencies and SME performance, the current study's results corroborate findings from past studies (Botha et al. 2015; Ikupolati et al. 2017; Lopa \& Bose 2014). As has been observed by Katz (2009), the appreciation of relationships among an enterprise's parts, afforded by conceptual competencies, enable owners and/or managers to act in ways which advance the overall welfare of the whole enterprise. Conceptual skills are more essential for managers than interpersonal or technical skills (Sidek \& Mohamad 2014). In addition, the highest level of leading change in the public sector required a set of conceptual skills that are critical for achieving the desired change (Jasim 2019). Middle managers were found to have a lower set of conceptual skills, and fewer skills were required at the third level of management (Jasim 2019). Past studies in developing countries (Benzing, Chu \& Bove 2005; Sidek \& Mohamad 2014) confirmed that conceptual skills of entrepreneurs were important to business growth. However, the aforementioned studies did not use hybrid or balanced approaches in their measurement of performance.

Generally, managerial competencies have been found to contribute directly to organisational performance (Agbenyegah \& Mahohoma 2020; Botha, Carruthers \& Venter 2019; Yusuf \& Suseno 2020). The main cause behind the failure of SMEs revolved around entrepreneurship management skills, be they labelled as financial management, human resource management, start-up, social and interpersonal, leadership, marketing, personality, business and technical management skills (Mamabolo et al. 2017). A study by Sánchez (2012) that used both financial and non-financial indicators to measure enterprise performance concluded that entrepreneurial competencies have both direct and indirect impact on SME performance via the mediating influence of organisational capabilities. Although scholars distinguish managerial competencies from entrepreneurial competencies (Lerner \& Almor 2002), some suggest competence in entrepreneurship requires competencies in both entrepreneurial and managerial competencies (Man, Lau \& Chan 2002). Another study by Mohsin etal. (2017) found out that entrepreneurial competencies were important for the success of Malaysian SMEs. They concluded that the success of Malaysian SMEs was largely dependent on the entrepreneurs' competencies in driving innovative performance. A related study by Al Mamun, Fazal and Muniady (2019), produced a path analysis and mediation test that proved that entrepreneurial skills and market orientation were critical enterprise resources that affected firm performance both directly and indirectly. The study also confirmed that networking was a critical resource influencing performance through entrepreneurial competencies. That being the case and especially given that SMEs tend to face limited resources, owners and/or managers should not only develop, but channel their competencies towards activities that have a bearing on enterprise performance.

Accordingly, the RBV, with its intra-organisational emphasis, holds that performance emanates from firm-specific capabilities and resources (Barney, Ketchen \& Wright 2011). The RBV is based on the fact that effective organisations will base their future competitiveness on developing unique capabilities, which may often be intangible or implicit in their nature - managerial conceptual competencies are one such capability. According to the RBV, in order for SMEs to attain competitive advantage, there is need for them to harness their internal resources to the fullest. In this vein, the current study validates the RBV, since statistically significant relationships between managerial conceptual competencies and SME performance as measured by both ROI and innovation were established. Specifically, the correlation between managerial conceptual competencies and the two measures of performance (ROI and innovation) were statistically significant at $1 \%$ as supported by p-values of 0.000 which are smaller than 0.01 . These results agree with those by Masoud and Al Khateeb (2020) which revealed that managerial competencies were significantly correlated to the performance of small businesses. The competencies referred to in the aforesaid study included planning and organising, scenario building, customer focus, strategic thinking and team work which happen to be so closely related to the conceptualisation of managerial conceptual competencies envisaged in the current study. Furthermore, the current study's findings corroborate an earlier study by Mashavira, Chipunza and Dzansi (2021) that also found a statistically significant relationship between managerial political competencies and enterprise performance. Although Mashavira et al. (2021) and Masoud and Al Khateeb (2020) used different sets of competencies to the one used in the current study, the relationship between managerial competencies (however defined) and performance seems to be supported empirically.

\section{Conclusions and recommendations}

Males dominated in either the ownership or management of SMEs and a majority of owners and/or managers had secondary education. Most of the participants in the survey were owners and/or managers, and very few enterprises had HR departments. The study established that owner and/or managers had reasonable levels of conceptual competencies and that SMEs performed fairly well in terms of both innovation and ROI. It was also established that statistically significant relationships existed between managerial conceptual competencies and SME performance as measured by both innovation and ROI. It can, therefore, be concluded that, the performance of SMEs with regards to ROI and innovation can be influenced by the owners and/or managers' levels of conceptual competencies.

Given the pivotal role managerial conceptual competencies play in SME performance, it is recommended that SME owners 
and/or managers invest in competence enhancement programmes and place more emphasis towards learning modern technologies to boost both innovation and enterprise profitability. In view of this, the Ministry of Small and Medium Enterprises and Cooperative Development and agencies like the SEDCO and others promoting entrepreneurship in Zimbabwe need to be recapitalised through more government funding to enable them to offer mentorship and learner-ship to owners and/or managers. This could, in a way, motivate enterprises set up HR departments since very few enterprises had such a department. In addition, since males dominated both ownership and management of the SMEs, it is also recommended that government should provide women with sponsored relevant entrepreneurial preparatory programmes in order to address historical gender imbalances. Robust and deliberate government policies meant to stimulate women's participation in entrepreneurial ventures should be put in place. No comprehensive data base of SMEs in the province could be found at the Ministry of Small and Medium Enterprises and Cooperative Development; the Informal Traders Association; the Informal Sector Association; and even at SEDCO. It is therefore recommended that government through the relevant ministry, agencies or associations fund the development of a reliable national database for start-ups and entrepreneurial ventures (which is not available at present) if any meaningful progress is to be achieved towards developing them sustainably.

\section{Limitations and directions for future studies}

Firstly, numerous competency models could be identified from literature; therefore, it may not be easy to isolate a specific competence and treat it independently, apart from others; since competencies are interdependent (SzczepańskaWoszczyna 2014) .Future studies may have to consider how clusters of interdependent competencies affect SME performance. Secondly, poor record keeping and informality characterising most SMEs meant that participants had to rely on their memory for most of the information. Thirdly, since the study made use of cross-sectional data for Harare Province, future studies should strive to gather longitudinal data involving nation-wide samples in order to validate and enhance the generalisability of findings of the current study.

\section{Contributions of the study}

From a theoretical viewpoint, this research contributed in validating the RBV by Barney (1991) through exploring the intangible managerial resource capabilities SMEs could leverage on to enhance their performance. Furthermore, a number of studies on managerial competencies (Hayton 2015; Lopa \& Bose 2014) were done in developed countries with different contextual realities from those obtained in Zimbabwe, where levels of managerial conceptual competencies and even the conceptualisation of SMEs differ significantly. Worse still, there is dearth of studies that specifically consider managerial conceptual competencies in Zimbabwe. In view of this, the current study is one of the very few, if any, that sheds light on the nexus between managerial conceptual competencies and SME performance, in an African country. The other contribution of the current study is in the area of performance measurement. The study adopted balanced measures of business performance by including a more recent, intangible and externally focused measure (innovation) to complement ROI - a more traditional financial measure (Bititci et al. 2013).

\section{Acknowledgements}

\section{Competing interests}

The authors declares that they have no competing interests.

\section{Authors' contributions}

N.M. \& C.C. contributed equally to this work.

\section{Funding information}

This research received no specific grant from any funding agency in the public, commercial, or not-for-profit sectors.

\section{Data availability}

Data had to be stored in ways that precluded unauthorised access in order to ensure confidentiality.

\section{Disclaimer}

The views and opinions expressed in this article are those of the authors and do not necessarily reflect the official policy or position of any affiliated agency of the authors.

\section{References}

Agbenyegah, A.T. \& Mahohoma, T., 2020, 'The impact of selected entrepreneuria competencies on SMEs performance in Ethekweni regions of South Africa: Theoretical and practical implications', Acta Universitatis Danubius: Oeconomica 16(4), 64-85.

Agyapong, A., Ellis, F. \& Domeher, D., 2016, 'Competitive strategy and erformance of family businesses: Moderating effect of managerial and innovative capabilities', Journal of Small Business and Entrepreneurship 28(6), 449-477. https://doi.org/1 0.1080/08276331.2016.1217727

Aidara, S., Mamun, A.A., Nasir, N.A.M., Mohiuddin, M., Nawi, N.C. \& Zainol, N.R. 2021, 'Competitive advantages of the relationship between entrepreneurial competencies and economic sustainability performance', Sustainability 13(2), 864. https://doi.org/10.3390/su13020864

Akinwale, Y.O., Adepoju, A.O. \& Olomu, M.O., 2017, 'The impact of technological innovation on SME's profitability in Nigeria', International Journal of Research Innovation and Commercialisation 1(1), 74-92. https://doi.org/10.1504/IJRIC 2017.082299

Alene, E.T., 2020, 'Determinants that influence the performance of women entrepreneurs in micro and small enterprises in Ethiopia', Journal of Innovation and Entrepeneurship 9, 24. https://doi.org/10.1186/s13731-020-00132-6.

Al Mamun, A., Fazal, S.A. \& Muniady, R., 2019, 'Entrepreneurial knowledge, skills, competencies and performance: A study of micro-enterprises in Kelantan, Malaysia', Asia Pacific Journal of Innovation and Entrepreneurship 13(1), 29-48. https://doi.org/10.1108/APJIE-11-2018-0067

Anwar, M., 2018, 'Business model innovation and SMEs performance: Does competitive advantage mediate?', International Journal of Innovation Management 22(7), 185-357. https://doi.org/10.1142/S1363919618500573

Barisic, A.F. \& Borisevic, M., 2013, 'Role of management consulting in a process of professionalization of SME management', Učenje Za Poduzetništvo/Entrepreneurial Learning 3(2), 144-160.

Barney, J.B., 1986a, 'Strategic factor markets: Expectations, luck, and the theory of business strategy', Management Science 32(10), 1512-1514.

Barney, J.B., 1986b, 'Organizational culture: Can it be a source of sustained competitive advantage', Academy of Management Review 11(3), 656-665.

Barney, J.B., 1991, 'Firm resources and sustained competitive advantage', Journal of Management 17(1), 99-120. 
Barney, J.B., 2001, 'Resource-based theories of competitive advantage: A ten-year retrospective on the resource-based view', Journal of Management 27(6), retrospective on the resource-based view', Journal of

Barney, J.B., Ketchen, D.E., Jr. \& Wright, M., 2011, 'The future of resource-based theory: Revitalization or decline?', Journal of Management 37(5), 1299-1315. https://doi.org/10.1177/0149206310391805

Becker, G.S., 1964, Human capital, Columbia University Press, New York, NY

Ben-Eliyahu, A., 2014, Understanding different types of research: What's the difference between qualitative and quantitative approaches?, viewed 15 September 2016, from http://chronicle.umbmentoring.org/on-methods-whats-the-differencebetween-qualitative-and-quantitative-approaches/.

Benzing, C., Chu, H.M. \& Bove, R., 2005, 'The motivation, problems and perceived success of entrepreneurs in Romania', Journal of the Academy of Business Administration 10(1/2), 73-88.

Bititci, U., Firat, S.U.O. \& Garengo, P., 2013, 'How to compare performances of firms operating in different sectors?', Production Planning and Control 24(12), 1-18. https://doi.org/10.1080/09537287.2011.643829

Botha, M., Carruthers, T.J. \& Venter, M.W., 2019, 'The relationship between entrepreneurial competencies and the recurring entrepreneurial intention and action of existing entrepreneurs', Southern African Journal of Entrepreneurship
and Small Business Management 11(1), a214. https://doi.org/10.4102/sajesbm. and Small

Botha, M. Van Vuuren, J.J. \& Kunene, T, 2015, 'An integrated entrepreneurial performance model focusing on the importance and proficiency of competencies performance model focusing on the importance and proficiency of competencies for start-up and established SMEs', South African Journa
39(3), 33-40. https://doi.org/10.4102/sajbm.v46i3.101

Bryman, A. \& Bell, E., 2007, Business research methods, 2nd edn., Oxford University Press, Oxford.

Bushe, B., 2019, 'The causes and impact of business failure among small to micro and medium enterprises in South Africa', Africa's Public Service Delivery and Performance Review 7(1), 1-26. https://doi.org/10.4102/apsdpr.v7i1.210

Cameron, K.S. \& Quinn, R.E., 2011, Management skills assessment instrument (MSAI), viewed 15 March 2018, from http://cf2015.bhcarroll.edu/files/session-1 congregational-development/quinn-and-cameron-management-skillsassessment-instrument pdf.

Cant, M.C. \& Wiid, J.A., 2013, 'Establishing the challenges affecting South African SMEs', International Business \& Economics Research Journal 12(6), 707-716. https://doi.org/10.19030/iber.v12i6.7869

Carranza, E., Dhakal, C. \& Love, I., 2018, Female entrepreneurs: How and why are they different?, World Bank, Washington, DC.

Chandler, G.N. \& Jansen, E., 1992, 'The founder's self-assessed competence and venture performance', Journal of Business Venturing 7(3), 223-236. https://doi. org/10.1016/0883-9026(92)90028-P

Chong, G.H., 2008, 'Measuring performance of small-and-medium sized enterprises: The grounded theory approach', Journal of Business and Public Affairs 2(1), 1-10.

Chundu, M., Pindiriri, C. \& Kaseke, N., 2020, 'Does size matter in determining growth of micro, small and medium enterprises (MSMEs) in Zimbabwe', Open Journal of Business and Management 8, 1888-1907.

Dekker, J., Lybaert, N., Steijvers, T. \& Depaire, B., 2015, 'The effect of family business professionalization as a multidimensional construct on firm performance', Journal of Small Business Management 53(2), 516-538.

De Souza, A.C., Alexandre, N.M.C., \& Guirardello, E.D., 2017, 'Psychometric properties in instruments evaluation of reliability and validity', Epidemiologia e serviços de saúde, Brasília 26(3), 1-10. https://doi.org/10.5123/S1679-49742017000300022

Detienne, D.R. \& Chandler, G.N., 2007, 'The role of gender in opportunity identification', Entrepreneurship Theory and Practice 31, 365-386. https://doi. org/10.1111/j.1540-6520.2007.00178.x

De Vos, A.S., Strydom, H., Fouché, C.B. \& Delport, C.S.L., 2011, Research at grassroots: For the social sciences and human services professions, 4th edn., Van Schaik Publishers, Cape Town.

Emenyoni, C.A., Nwosu, A.C., Lemchi, J.I. \& Iheke, O.R., 2014, 'Analysis of productivity, profitability, incomes and return on investments in youth SMEs in Niger Delta', Nigeria, International Journal of Small Business and Entrepreneurship Research 2(1), 20-34

Evangelista, L., 2011, Study on Existing Frameworks to Validate Competence of Career Guidance Practitioners, European Commission, Brussels, viewed 08 August 2011 from http://www.improveguidance.eu/sites/default/files/Issues-08082011.pdf.

Fatoki, O., 2014, 'The impact of managerial competencies on the performance of immigrant- owned enterprises in South Africa', Mediterranean Journal of Social Sciences 5(6), 141-144. https://doi.org/10.5901/mjss.2014.v5n6p141

FinScope MSME Survey Zimbabwe, 2013, Fin mark Trust, viewed 02 September 2017, from https://finmark.org.za/finscope-msme-survey-zimbabwe-2012/.

Forth, J. \& Bryson, A., 2018, The impact of management practices on SME performance, Discussion Paper Series, IZA - Institute of Labor Economics, Bonn, pp. 1-38.

Gizaw, Y., Tsega, S. \& Hailegiorgis, K., 2019, 'Assessment of the challenges and opportunities of women entrepreneurs, in, Assessment of the challenges and opportunities of women entrepreneurs in Sodo Town, Wolaita Zone, SNNPR Asian Journal of Economics, Business and Accounting 10(1), 1-8. https://doi. org/10.9734/AJEBA/2019/v10i130097

Grant, R.M., 1991, 'The resource-based theory of competitive advantage: Implications for strategy formulation', California Management Review 33(3), 114-135. https:// doi.org/10.2307/41166664

Gray, D.E., 2014, Doing research in the real world, 3rd edn., SAGE, Los Angeles, CA.
Gunawan, J. \& Aungsuroch, Y., 2017, 'Managerial competence of first - Line nurse managers: A concept analysis', International Journal of Nursing Practice 23(1), e12502. https://doi.org/10.1111/ijn.12502

Gupta, V.K. \& Batra, S., 2016, 'Entrepreneurial orientation and firm performance in Indian SMEs: Universal and contingency perspectives', International Small Business Journal: Researching Entrepreneurship 34(5), 660-682. https://doi. org/10.1177/0266242615577708

Gwatsvaira, O. \& Mtisi, S., 2016, 'An investigation into the factors contributing to lack of growth of small and medium enterprises (SMEs) in the furniture manufacturing industry in Kelvin North, Bulawayo, Zimbabwe', The International Journal of Business \& Management 4(12), 1-12.

Hamid, I.Z.A, Azizan, N.A. \& Sorooshian, S., 2018, 'Predictors for the success and survival of entrepreneurs in the construction industry', International Journal of Engineering Business Management 7(1), 1-8.

Hayton, J., 2015, Leadership and management skills in SMEs: Measuring associations with management practices and performance, Department of Business, Innovation and Skills, BIS Research Paper Number 224, viewed n.d., from https:// assets.publishing.service.gov.uk/government/uploads/system/uploads/ attachment_data/file/418404/bis-15-204-leadership-and-management-skills-insme.pdf.

Herrington, M. \& Wood, E., 2003, Global Entrepreneurship Monitor, South African Report, viewed 18 March 2016, from http://www.gbs.nct.ac.za/gbswebb/ userfiles/gemsouthafrica2000pdf.

Hervas-Oliver, J.L., Sempere-Ripoll, F. \& Boronat-Moll, C., 2014, 'Process innovation strategy in SMEs, organizational innovation and performance: A misleading debate?', Small Business Economics 43(4), 873-886. https://doi.org/10.1007/ s11187-014-9567-3

Hughes, C., 2006, Qualitative and quantitative approaches to social research, viewed 24 February 2014, form http://www2.warwick.ac.uk/fac/soc/sociology/staff/ hughes/researchprocess/quantitative_and_qualitative_approaches.docx.

Hundley, G., 2001, 'Why women earn less in self-employment', Journal of Labour Research 22(4), 817-829. https://doi.org/10.1007/s12122-001-1054-3

Ikupolati, A.O.P., Adeyeye, M.M., Oni, E.O., Olatunle, M.A. \& Obafunmi, M.O., 2017 'Entrepreneurs' managerial skills as determinants for growth of small and medium enterprises (SMEs) in Nigeria', Journal of Small Business and Entrepreneurship Development 5(1), 1-6. https://doi.org/10.15640/jsbed.v5n1a1

Ismanu, S., Salim, U., Moeljadi, S.A., 2017, 'The effect of innovation strategy on financial performance small and medium enterprises in Indonesia', International Journal of Applied Business and Economic Research 15(12), 365-379.

Jasim, A.F.A., 2019, 'Conceptual skills in leading change: A competence approach to public sector leadership', A thesis Submitted to the Faculty of Law and Business in fulfilment of the requirements for the degree of $\mathrm{PhD}$ in Business Management at The British University in Dubai February 2019.

Jennings, J.E. \& Cash, M.P., 2006, 'Women's entrepreneurship in Canada: Progress, puzzles and priorities', in C.G. Brush et al. (eds.), Growth-oriented women entrepreneurs and their businesses, pp. 53-87, Edward Elgar Publishing, Northampton, MA.

Johari, R.J., Tarmizi, M., Mohd, H. \& Rashid, N., 2018, 'A revisited note on internal audit function and good corporate governance a revisited note on internal audit function and good corporate governance', International Journal of Academic Research in Business and Social Sciences 8(12), 716-728. https://doi.org/10.6007/ Research in Business
IJARBSS/v8-i12/5067

Jongwe, A., 2013, An agenda for support for SMEs, Financial Gazette, 31 January.

Kotane, I. \& Kurzimina-Merlino, I., 2017, 'Analysis of small and medium sized enterprises' business performance evaluation practice at transportation and storage services sector in Latvia', Procedia Engineering 178(2017), 182-191. storage services sector in Latvia', Procedia
https://doi.org/10.1016/j.proeng.2017.01.093

Katz, R.L., 2009, Skills of an effective administrator, 2nd edn., Harvard Business School Publishing, Boston, MA.

Kaur, S.P., 2013, 'Variables in research', IJRRMS 3(4), 36-38.

Kawaza, K., 2014, Massive retrenchments in first 2014 quarter, 23 May 2014 Zimbabwe Independent, viewed n.d., from https://www.theindependent.co. zw/2014/05/23/massive-retrenchments-first-2014-quarter/.

Klapper, L.F. \& Parker, S.C., 2011, 'Gender and the business environment for new firm creation', World Bank Research Observer 26(2), 237-257. https://doi.org/10.1093/ wbro/lkp032

Kraaijenbrink, J., Spender, J.C. \& Groen, A.J., 2009, 'The resource-based view: A review and assessment of its critiques', Journal of Management 36(1), 349-372.

Königová, K., Urbancová, H. \& Fejfar, J., 2012, 'Identification of managerial competencies in knowledge-based organizations', Journal of Competitiveness 4(1), 129-142. https://doi.org/10.7441/joc.2012.01.10

Lee, B., 2012, Financial guide for small and medium enterprises, CPA Australia Ltd., Singapore.

Lerner, M. \& Almor, T., 2002, 'Relationships among strategic capabilities and the performance of women-owned small ventures', Journal of Small Business Management 40(2), 109-125. https://doi.org/10.1111/1540-627X.00044

Li, X., Jiang, B. \& Li, J.2 2020, 'Adoption of supply chain finance by small and medium enterprises in China', Business Process Management Journal 27(2), 486-504. https://doi.org/10.1108/BPMJ-09-2020-0399

Lockett, A., \& Thompson, S., 2001, 'The resource-based view and economics', Journal of Management 27(6), 723-754. 
Lopa, N.Z. \& Bose, T.K., 2014, 'Relationship between entrepreneurial competencies of SME owners/managers and firm performance: A study on manufacturing SMEs in Khulna City', Journal of Entrepreneurship and Management 3(3), 1-12.

Lopez-Nicolas, C., Nikou, S., Molina-Castillo, F.-J. \& Bouwman, H., 2020, 'Gender differences and business model experimentation in European SMEs', Journal of
Business \& Industrial Marketing 35(7), 1205-1219. https://doi.org/10.1108/JBIM05-2019-0194

Madzivanzira, A., 2011, SMEs key to economic recovery, The Patriot, viewed 06 January 2016, form http://www.thepatriot.co.zw/old_posts/smes-key-toeconomic-recovery/.

Mahadalle, A. \& Kaplan, B., 2017, 'Entrepreneurial characteristics and competencies as determinants of corporate performance: A study on small enterprises in Mogadishu, Somalia', International Journal of Research-Granthaalayah 5(5), 243-254. https://doi.org/10.29121/granthaalayah.v5.i5.2017.1856

Majukwa, D., 2019, 'Sustainability strategies for small and medium sized enterprise in Zimbabwe', Doctoral Study Submitted in Partial Fulfillment of the Requirements for the Degree of Doctor of Business Administration, Walden University.

Makanyeza, C. \& Dzvuke, G., 2015, 'The influence of innovation on the performance of small and medium enterprises in Zimbabwe', Journal of African Business 16(1-2), 198-214. https://doi.org/10.1080/15228916.2015.1061406

Malhotra, N.K., Nunan, D., Birks, D.F. \& Wills, P., 2017, Marketing research: An applied approach, 5th edn., Pearson Education Ltd., London.

Mamabolo, M.A., Kerrin, M. \& Kele, T., 2017, 'Entrepreneurship management skills requirements in an emerging economy: A South African outlook', Southern African Journal of Entrepreneurship and Small Business Management 9(1), a111. https:// doi.org/10.4102/sajesbm.v9i1.111

Man, T., Lau, T. \& Chan, K.F., 2002, 'The competitiveness of small and medium enterprises. A conceptualisation with focus on entrepreneurial competencies', Journal of BusinessVenturing 17(2), 123-142. https://doi.org/10.1016/S0883-9026(00)00058-6

Manxhari, M., Veliu, L. \& Jashari, J., 2017, 'Developing models of manageria competencies of managers: A review', International Journal of Economics, Commerce and Management 4, 186-200.

Maseko, N. \& Manyani, O., 2011, 'Accounting practices of SMEs in Zimbabwe: An investigative study of record keeping for performance measurement (a case stud of Bindura)', Journal of Accounting and Taxation 3(8), 171-181. https://doi. org/10.5897/JAT11.031

Mashavira, N., Chipunza, C. \& Dzansi, D.Y., 2021, 'Managerial political competencies and the performance of small and medium-sized enterprises in South Africa', Acto Commercii 21(1), a884. https://doi.org/10.4102/ac.v21i1.884

Masoud, E.Y. \& Al Khateeb, L., 2020, 'The influence of managerial competencies on the business performance in the small business funded by Jordan River Foundation', European Journal of Business and Management 12(20), 49-59.

Matthews, B. \& Ross, L., 2010, Research methods: A practical guide for the social sciences research, Pearson Education Limited, London.

Minniti, M., 2017, Female entrepreneurship, role models and network externalities in middle-income countries, The Routledge Companion to Global Female Entrepreneurship, Routledge, Abingdon, pp. 197-213.

Mitchelmore, S. \& Rowley, J., 2010, 'Entrepreneurial competencies: A literature review and development agenda', International Journal of Entrepreneurial Behavior \& Research 16(2), 92-111. https://doi.org/10.1108/13552551011 026995

Mohsin, M.B.A., Halim, H.A., Ahmad, N.H. \& Farhan, N., 2017, 'Assessing the role of entrepreneurial competencies on innovation performance: A partial least square (PLS) approach', The Journal of Business Inquiry 16(Special Issue 1), 88-101.

Motlaq, M.A., Motlaq, M.A., Dareke, M. \& Rezaei, H., 2012, 'The effect of conceptual skills training on the degree of job satisfaction and performance in women managers', The First International Conference of Women's Health, Shiraz, Iran, June 14-15, 2012.

Mozumdar, L., Van Der Velde, G. \& Omta, S.W.F., 2020, 'Determinants of the business performance of women entrepreneurs in the developing world context', MDPI, Multidisciplinary Scientific Journal 3(2), 215-235. https://doi.org/10.3390/ j3020017

Mpando, I.T., 2015, 'An assessment of the impact of innovation \& business networks on the performance of SMEs in the Harare Metropolitan', Unpublished Master's thesis, University of Zimbabwe.

Mucheche, C., 2017, Amendments to the Zimbabwean Labour Act [Chapter 28:01] and their Implications on the Employment Relationship: A Review of Some Critical Sections of the Labour Amendment Act No. 5 of 2015, The Zimbabwe Electronic Sections of the Labour Amendment Act No. 5 of 2015, The
Law Journal, Zimbabwe Legal Information Institute, Harare.

Mukoswa, M.C., 2020, 'The survival of Foreign nationals' small businesses in Johannesburg', Master's dissertation, University of Johannesburg, Johannesburg, viewed 04 March 2021, from http://hdl.handle.net/102000/0002.

Mustafa, A. \& Ayse, P., 2017, 'Managerial competencies and impact on management levels', International Journal of Advanced Research in Management and Social Sciences 6(9), 1-16.

Naudé, W. (ed.), 2013, Entrepreneurship and economic development theory, Evidence and Policy, IZA Discussion Paper Number 7507, in Entrepreneurship and Economic Development, Palgrave Macmillan, New York, p. 304.

Ncube, M.S. \& Chimucheka, T., 2019, 'The effect of managerial competencies on the performance of small and medium enterprises in Makana Municipality, South Africa', African Journal of Hospitality, Tourism and Leisure 8(5), 1-15.

Nerisa, P., 2015, 'Business university student entrepreneurial competencies: Towards readiness for globalization', in Proceedings of the Second European Academic Research Conference on Global Business, Economics, Finance \& Banking, Zurich, 3rd-5th July, Paper Id: Z549.
Njanike, K., 2019, The factors influencing SMEs growth in Africa: A case of SMEs in Zimbabwe, Regional Development in Africa, IntechOpen Limited, London.

Norman, G., Norcini, J. \& Bordage, G., 2014, 'Competency-based education: Milestones or millstones?', Journal of Graduate Medical Education 6(1), 1-6. https://doi.org/10.4300/jgme-d-13-00445.1

Nyathi, K.A., Nyoni, T., Nyoni, M. \& Bonga, W.G., 2018, 'The role of accounting information in the success of small \& medium enterprises (SMEs) in Zimbabwe: $A$ case of Harare', Journal of Business and Management (DRJ-JBM) 1(1), 01-15.

Ofei, A.M.A., Paarima, Y. \& Barnes, T., 2020, 'Exploring the management competencies of nurse managers in the Greater Accra Region, Ghana', International Journal of Africa Nursing Sciences 13, 1-7. https://doi.org/10.1016/j.ijans.2020.100248

Organisation for Economic Cooperation and Development, 2017, 'Enhancing the contributions of SMEs in a global and digitalised economy', Meeting of the OECD Council At Ministerial Level Paris, 7th-8th June 2017.

Organisation for Economic Cooperation and Development, 2018, 'Promoting innovation in established SMEs, Parallel Session 4', SME Ministerial Conference, innovation in established SMEs, Paralle

Papulová, Z. \& Mokroš, M., 2007, Importance of managerial skills and knowledge in management for small entrepreneurs, E-Leader, Prague, pp. 1-8.

Pekkola, S., Saunila, M. \& Rantanen, H., 2016, 'Performance measurement system implementation in a turbulent operating environment', International Journal of Productivity \& Performance Management 65(7), 947-958. https://doi. org/10.1108/IJPPM-01-2015-0018

Penrose, E., 1959, The Theory of the Growth of the Firm. Wiley, New York, NY.

Peteraf, M.A., 1993, 'The cornerstone of competitive advantage: A resource - based view', Strategic Management Journal 14(3), 179-191.

Rosli, M.M. \& Sidek, S., 2013, 'The impact of innovation on the performance of smal and medium manufacturing enterprises: Evidence from Malaysia', Journal of Innovation Management in Small \& Medium Enterprise 2013, 1-16. https://doi. org/10.5171/2013.885666

Rumelt, R.P., 1987, 'Theory, strategy, and entrepreneurship', in D.J. Teece (ed.), The competitive challenge, pp. 137-158, Ballinger Publishing Company, Cambridge, MA.

Rutherford, M.W., Buller, P.F. \& McMullen, P.R., 2004, 'Human resource management problems over the life cycle of small to medium-sized firms', Human Resource Management 42(4), 321-335.

Saka, A.B. \& Chan, D.W.M., 2020, 'Adoption and implementation of building information modelling (BIM) in small and medium-sized enterprises (SMEs): A review and conceptualization', Engineering, Construction and Architectural Management 28(7), 1829-1862. https://doi.org/10.1108/ecam-06-2019-0332

Salleh, F., Ibrahim, M.D., Yazid, A.S., Afthanorhan, A., Rashid, N. \& Ghazali, P.L., 2018 'Micro small and medium enterprise demand for general Takaful: Proposed theoretical framework and hypotheses development', International Journal of Academic Research in Business and Social Sciences 8(12), 599-612. https://doi. org/10.6007/IJARBSS/v8-i12/5058

Sánchez, J., 2012, 'The influence of entrepreneurial competencies on small firm performance, the influence of entrepreneurial competencies on small firm performance', Revista Latinoamericana de Psicología 44(2), 165-177.

Sandada, M. \& Mangwandi, L., 2015, 'An assessment of the influence of selected SMEs on the performance of small to medium sized family owned businesses in the Zimbabwe retail sector', Audoe 11(5), 5-16.

Sangoseni, O., Hellman, M. \& Hill, C., 2013, 'Development and validation of a questionnaire to assess the effect of online learning on behaviors, attitude and clinical practices of physical therapists in United States regarding of evidence-based practice', Internet Journal of Allied Health Science Practice 11, 1-12.

Santos, F.M. \& Bode, C.S., 2012, The organizational foundations of corporate social entrepreneurship, viewed 12 September 2018, from http://www.insead.edu.

Schumpeter, J.A., 1934, The theory of economic development: An inquiry into profits, capital, credits, interest, and the business cycle, Transaction Publishers, Piscataway, NJ.

Shava, H. \& Rungani, E.C., 2016, 'Influence of gender on SME performance in emerging economies', Acta Commercii 16(1), a408. https://doi.org/10.4102/ac.v16i1.408

Shouyu, C., 2017, 'The relationship between innovation and firm performance: A literature review', Advances in Computer Science Research 82, 648-652.

Sidek, S. \& Mohamad, M.R., 2014, 'Managerial competencies and small business growth: Empirical evidence from microfinance participants', IJMS 21(1), 39-59. https://doi.org/10.32890/ijms.21.1.2014.10404

Singh, R., Rigsby, J. \& Ramgulam, N., 2018, 'Formal human resource management (HRM) practices and the performance of small and medium-sized enterprises (SMEs): A study of SMEs in the Caribbean nation of Trinidad', Journal of Eastern (SMEs): A study of SMEs in the
Caribbean Studies $42(2), 1-36$.

Szczepańska-Woszczyna, K., 2014, 'SMEs managers - A need for competence', Acta Technologica Dubnicae 4(1), 1-16. https://doi.org/10.1515/atd-2015-0008

The Zimind, 2017, SMEs hold key to economic growth, viewed 21 February 2017, from https://www.thestandard.co.zw/2011/10/23/smes-hold-key-to-economic-growth/.

Tocher, N. \& Rutherford, M.W., 2009, 'Perceived acute human resource management problems in small and medium firms: An empirical examination', Entrepreneurship Theory and Practice 33(2), 455-479. https://doi.org/10.1111/j.1540-6520.2009.00299.x

Tola, Z. \& Chimucheka, T., 2018, 'The importance of entrepreneurial competencies on the performance of women entrepreneurs In South Africa', The Journal of Applied Business Research 34(2), 223-236. https://doi.org/10.19030/jabr.v34i2.10122

Umer, M., 2012, 'Human resource management theory and practices in small and medium-sized enterprises (SMEs) and enterprises performance in Pakistan', Global Journal of Management and Business Research 12(13), 28-44. 
University Canada West, 2021, How can you improve your managerial skills?, viewed 26 May 2021, from https://www.ucanwest.ca/blog/education-careers-tips/howcan-you-improve-your-managerial-skills.

Veliu, L. \& Manxhari, M., 2017, 'The impact of managerial competencies on business performance: SMEs in Kosovo', Vadyba Journal of Management 1(30), 59-65.

Vijay, L. \& Ajay, V.K., 2011, 'Entrepreneurial competency in SME's', Bonfring International Journal of Industrial Engineering and Management Science 1(Special Issue), 5-10. https://doi.org/10.9756/BIJIEMS.1002

Wilk, E.O. \& Fensterseifer, J.E., 2003, 'Use of resource-based view in industrial cluster strategic analysis', International Journal of Operation and Production Management 23(9), 995-1009.

Wernerfelt, B., 1984, 'A resource-based view of the firm', Strategic Management Journal 5(2), 171-180.

Wernerfelt, B., 1995, 'The resource-based view of the firm: Ten years after', Strategic Management Journal 16(3), 171-174.

Wyllie, T.M., 2019, Qualitative and quantitative research approaches, pp. 1-10, UNICAF University, Malawi.
Xiang, D., Worthington, A.C. \& Higgs, H., 2014, 'Discouraged finance seekers: An analysis of Australian small and medium-sized enterprises', International Small Business Journal 33(7), 689-707. https://doi.org/10.1177/0266242613516138

Yip, G.S., Devinney, T.M. \& Johnson, G., 2009, 'Measuring long term superio performance: The UK's long-term superior performers 1984-2003', Long Range Planning 42, 390-413.

Yuliandi, S., 2014, 'Influence of competency, knowledge and role ambiguity on job performance and implication for PPAT performance', Journal of Economics and Sustainable Development 5(12), 111-116.

Yusuf, F.A. \& Suseno, B.D., 2020, 'Sustainability innovativeness agility as an intervening variable in the managerial competence to business performance relationship of a family-owned company', International Journal of Innovation, Creativity and Change 13(9), 479-498.

Zindiye, S., Chiliya, N. \&Masocha, R., 2012, 'The impact of government and other institutions' support on the performance of small and medium enterprises in the manufacturing sector in Harare, Zimbabwe', International Journal of Business Management and Economic Research 3(6), 655-667. https://doi.org/10.5897/ AJBM11.2387 